\section{Zoran Pavlović1}

Department of Psychology, Faculty of Philosophy, University of Belgrade, Serbia

\section{Bojan Todosijević}

\section{Centre for} politicological research and public opinion, Institute of Social Sciences, Serbia

1 Author's address: zoran.pavlovic@f.bg.ac.rs.

\section{AUTHORITARIANISM AND COGNITIVE POLITICAL INVOLVEMENT}

This study analyses the linkage between authoritarianism and three indicators that describe one's general cognitive orientation towards the world of politics: political knowledge, general interest in politics, and interest in the election campaign. Individuals high in authoritarianism are hypothesized to be less politically competent and less interested in politics, due to their resistance to adopting new information and to changing the adopted beliefs. This hypothesis is based on the classical description of the authoritarian personality, but it has not been adequately empirically verified yet. The data are taken from a post-election public opinion survey conducted in 2012 after the presidential and parliamentary elections, on a random sample of voting age citizens of Serbia $(N=1568)$. The results show that authoritarianism and the level of political knowledge are significantly and negatively correlated, even after controlling for the basic socio-demographic variables. The intensity of political interest is not significantly correlated with authoritarianism. Additional comparison of the misinformed and uninformed groups (those who provided incorrect answers, and those who answered "don't know", respectively) did not support the view that authoritarian persons are more inclined to erroneously guess an answer than to simply say "don't know". The study concludes that the association between political knowledge and authoritarianism is based on deeper psychological roots, while the (lack of) association with political interest is likely to be context-dependent.

Keywords: authoritarianism, political knowledge, political interest, Serbia

Primljeno: 10. 12. 2017.

Primljena korekcija:

19. 12. 2017.

Prihvaćeno za štampu:

25. 12. 2017. 
Since the publishing of the seminal work on authoritarian personality by Adorno and associates (Adorno, Frenkel-Brunswik, Levinson, \& Sanford, 1950), authoritarianism has become one of the most influential concepts in political psychology. The literature on authoritarianism describes highly authoritarian individuals as prejudiced and intolerant, prone to antidemocratic, non-egalitarian ideologies. Numerous empirical studies have shown the link between authoritarianism and ethnic (Adorno et al., 1950; Brown, 1965) and non-ethnic prejudice (Peterson, Doty, \& Winter, 1993), nationalism (Todosijević, 2013), the militarist view on conflict resolution (Doty, Winter, Peterson, \& Kemmelmeier, 1997), procapitalist attitudes, denial of freedom and human rights etc. (Altemeyer, 1981, 1988, 1996; McFarland, 2010; Meloen, 1993). In a nutshell, the extant evidence shows that authoritarian individuals hold specific views on social and political issues, which consequently determines their political preferences and behaviour.

The correlates of authoritarianism have mostly been sought (and found) in the field of attitudes towards various social and political issues (e.g., McFarland, 2010; Meloen, 1993). The relationship between authoritarianism and political cognition is, however, an under-researched area, although the topic is both theoretically and practically important. The literature on authoritarianism contains numerous references to specific features of political cognition and involvement among the highly authoritarian individuals that require empirical verification and further theoretical development. Yet, as Peterson et al. (Peterson, Duncan, \& Pang, 2002) complained some time ago, "To date [...], no one has examined the amount of political knowledge possessed by someone scoring high on authoritarianism." (pp. 99-100, emphasis in original). Peterson et al. (2002) reported a negative association between the right-wing authoritarianism and both political knowledge and political interest among American university students.

The situation in the research field has not changed much meanwhile. The studies on authoritarianism and political involvement and interest are still scarce. In particular, research evidence from different political and cultural contexts, as well as the studies on large, probability samples, would be most welcome. This paper's contribution is in providing the lacking empirical evidence, using reliable measurement instruments and a large, probability-based sample. The evidence comes from Serbia, a still-democratizing country, with recent experience with authoritarian politics.

\section{Authoritarianism and political involvement: The theoretical framework}

“The Authoritarian Personality" (Adorno et al., 1950) contains numerous references to the authoritarians' view of the political world. Although Adorno and associates treated authoritarianism as a personality concept, and "personality may be regarded as a determinant of ideological preferences" (Adorno et al., 1950, 
p. 5, italics in original), throughout the pages of "The Authoritarian Personality" there are explicit references to prominent political cynicism and aversion towards politics and politicians, as well as to political ignorance of highly authoritarian individuals. For instance, the interviews revealed, "widespread ignorance and confusion (...) in political matters, a phenomenon which might well surpass what even a skeptical observer should have anticipated" (Adorno et al., 1950, p. 658).

Moreover, a kind of an anti-political orientation is observed among the authoritarian respondents. Politicians and bureaucrats were perceived as "usurpers, parasites, know nothing about the people (...). The wealth of statements against bureaucrats and politicians in our interview material is tremendous." (Adorno et al., 1950, pp. 693-694). Yet, it is not known to what extent such description, that is, political ignorance and disinterest in politics, fits the contemporary authoritarianism.

Authoritarian individuals appear as "apolitical animals" in Altemeyer's outline of the right-wing authoritarianism as well. Altemeyer (1988) corroborates Adorno et al.'s view that authoritarianism leads to obedience to the authorities perceived to be legitimate (i.e., political passivity). However, he also emphasizes that right-wing authoritarianism "connects only moderately to the political preferences of ordinary people" (Altemeyer, 2007, p. 197), thus implying not only the lack of political interest, but also political incompetence - the difficulty in connecting one's attitudes with political choices.

In some other conceptions, authoritarianism has been equaled with the quality of person's cognitive functioning. Rokeach (1960) argued that dogmatism, a form of a belief system structure, could be understood as the general authoritarianism. Dogmatic persons are described as closed-minded, as individuals whose processing of political information is suboptimal. This line of reasoning emphasizes the importance not of the content of one's beliefs, but of the cognitive structure - the biased acquisition, selection, and interpretation of information. This view is supported by empirical evidence that shows that more authoritarian/ conservative individuals are less politically sophisticated (Tetlock, 1983), think less analytically (Talhelm et al., 2015) and show low cognitive complexity (Hinze, Doster, \& Joe, 1997). Likewise, recent research on conservatism as motivated social cognition (Jost \& Amodio, 2012; Jost, Kruglanski, Glaser, \& Sulloway, 2003) also points in the direction of authoritarian political views being associated with the biased processing of political information.

In Adorno et al.'s conceptualization, authoritarianism is a personality disposition, and therefore causally prior to consequent deficient political knowledge and interest. The causal order could, however, be conceived differently. The authors themselves recognized that "there is a reason to believe that ignorance itself works in favour of general reactionary trends" (Adorno et al., 1950, p. 339). The claim is nicely illustrated with some interesting findings that Gordon Allport discusses in his classic work on prejudice (Allport, 1954). He argues of prejudiced people as being afraid to say "don't know". They need for definiteness and feel 
secure when they "know" the answer, even if it means making erroneous guesses. Those higher on authoritarianism would demand a clear-cut structure of the social world; they are intolerant of uncertainty and "not knowing", even if the alternative is an inadequate piece of information (Allport, 1954). Put simply, people higher on authoritarianism could be expected to be rather misinformed than uninformed, the difference which has evidenced political relevance (Kuklinski, Quirk, Jerit, Schweider, \& Reich, 2000).

Similarly, Lipset (1959) argued that the firmly established link between low socioeconomic status and high authoritarian predispositions is moderated by the lack of political sophistication. The less sophisticated the individual, "the more likely he is to favour a simplified and demonological view of politics" (Lipset, 1959 , p. 492). Put simply, the lack of information, among other things, predisposes a person to view politics in simplistic, "black and white" terms and to prefer extremist movements, quick and easy solutions to social problems - in other words, makes the person more prone to an authoritarian political outlook. A sort of a cognitive approach to authoritarianism or, as others suggested (Meloen, 1996), the lack-of-cognitive-understanding approach to the study of authoritarianism could be quite appropriate as well.

Indeed, if we look at political knowledge, it is typically described as something antithetical to authoritarianism. Numerous studies have shown that increased political knowledge is related to some of the most prominent features of a democratic political outlook, such as more active participation in various political activities (Delli Carpini \& Keeter, 1996; Inglehart, 1979; Klingemann, 1979; Krampen, 2000; Pavlović, 2012; 2013a) and increased political tolerance (Delli Carpini \& Keeter, 1996; Pavlović, 2012). Some argue that political knowledge is "to democratic politics what money is to economics: it is the currency of citizenship" (Delli Carpini \& Keeter, 1996, p. 8). Knowledgeable individuals are supposed to make more informed and rational political decisions, to monitor political process more closely and "press" political authorities to be more accountable and responsible. Such activities are quite the opposite of what is to be expected of an authoritarian personality.

Political knowledge and interest are often viewed as key components of democratic political competences, while political ignorance and indifference are opposite (e.g., Dekker, 1996). Furthermore, political knowledge and political interest are usually treated as measures of cognitive mobilization (Dalton 1984, 2007), a notion used in describing the changing trends in political behaviour. It is argued that, due to rising levels of education, media proliferation, and information access, people became more cognitively mobilized. They are well equipped with skills and resources to make their own independent political decisions without relying on affective or habitual cues (Dalton, 1984, 2007; Dalton \& Wattenberg, 2000).

The socio-psychological research on cognitive closure additionally corroborates the view that cognitive factors are causally prior to authoritarianism. For instance, Chirumbolo concluded that "authoritarianism seems to mediate the influence of 
need for closure on political orientation" (2001, p. 603, abstr.). Likewise, Roets and Van Hiel (2006) also report that right-wing authoritarianism mediates between cognitive closure and conservatism. It is important to note here that the need for cognitive closure refers to non-political cognitive functioning. In this paper, we deal with explicitly political knowledge and interest, and therefore authoritarianism is more likely to function as a precursor of specific forms of political involvement.

\section{The present research}

Regardless of the causal priority, various approaches briefly outlined above all suggest that authoritarianism should be associated with lower political knowledge and the lack of interest in politics. The present study is aimed at analysing the relationship between authoritarianism and three key indicators of cognitive, political involvement: political knowledge, general political interest, and interest in the election campaign. Thus, we will focus on the link between authoritarianism and a general cognitive orientation towards the political world.

In the single existing study that addressed the same problem, Peterson et al. (2002) reported significant negative correlations between the right-wing authoritarianism (RWA) and political knowledge among American college students. Those high on the right-wing authoritarianism possessed the less general political knowledge and fewer pieces of specific information related to the 2000 US Presidential elections (see Peterson, Smirles, \& Wentworth, 1997). Similarly, interest in politics was lower in the highly authoritarian group. The individuals who scored high on authoritarianism were described as persons alienated and excluded from the political process, which they perceived in terms of rigid categories and impermeable constructs (Peterson et al., 2002).

Our hypothesis about political knowledge resembles the one advanced by Peterson et al. (2002). Given the cognitive rigidity associated with authoritarianism, we would expect that high authoritarians are prone to endorsing the biased views of the political world, relatively less likely to change their incorrect beliefs and to adopt new information that may affect their already existing opinions. The association of authoritarianism with political interest is somewhat less straightforward. As suggested by Peterson et al. (2002), the cognitive closure may predispose one not to seek additional information (given the pre-existing beliefs), and therefore to express lower political interest. Analogously, individuals low in authoritarianism, who are known to show higher openness to experience (e.g., McCrae, 1996), could be expected to show more political interest as well. Peterson et al. (1997, 2002), for instance, provided evidence of a negative association between authoritarianism and political interest.

However, they also proposed that "the lack of any positive relationships between authoritarianism and political interest may indicate that people scoring high on RWA are rather apathetic about politics until social threats begin to accu- 
mulate" (Peterson et al., 2002, p. 107). Indeed, a recent political upheaval across Europe showed that right-wing extremist (and therefore authoritarian) groups and organizations were the first to mobilize and give voice to their negative attitudes towards the Syrian (and other) refugees. Hence, we expect to obtain evidence of a negative association between political interest and authoritarianism, but bearing in mind the possibility that authoritarianism may be associated with attentiveness to certain political issues contrary evidence seems possible as well.

To summarize, we add to the existing knowledge in several ways. First, we provide fresh empirical evidence on an important but understudied problem. In fact, we aim to provide contextualized evidence, which is particularly needed since the main hypotheses are formulated in a general manner, i.e., not restricted to a specific political and cultural context. Of particular importance is that the analysis is based on the data obtained from a large, national level probability sample. Peterson et al. (2002) used small psychology student samples - as is typical for much of social psychology research. Their respondents, the students of the average age of 18 , were certainly not representative of general population either in political knowledge (should be much better informed) or in authoritarianism (psychology students should be low). The authors themselves acknowledged this problem, and suggested "collecting data from people of diverse ages and education levels" (Peterson et al., 2002, p. 108). They also suggested the need to analyse the authoritarianism-political interest association in larger, more diverse samples, which would be important for studying political interest. They speculate that highly authoritarian individuals might, in fact, be a particularly politically involved group, but such individuals might be rare in the usual psychology student samples.

Finally, we devote some attention to the role of education and age in the relationship between authoritarianism and political involvement. Namely, it is known that the latter two variables are associated with education and age. Hence, the association between them might be spurious. For this reason, we compare zeroorder associations with those obtained after controlling for the influence of age and education.

Research of the outlined problems gains additional relevance in an unstable political context, such as Serbia. In a number of studies, authoritarianism proved to be an important factor in understanding political attitudes and behaviour in this context, and is often viewed as a major obstacle in the process of democratization of the society. For example, it strongly differentiates the supporters of main political parties in Serbia (Kuzmanović, 2010; Pantić \& Pavlović, 2009; Todosijević, 2006, 2013; Todosijević, Pavlović, \& Komar, 2015) and negatively influences the support for democracy in general (Pavlović, 2013b, 2014). If those higher on authoritarianism are indeed more cognitively involved in politics, then authoritarianism itself can be viewed as an important driving force of political behaviour and a "threat" to democracy. Still, if, as expected, authoritarianism leads 
to political withdrawal and disinterest, its role in political behaviour should be understood quite differently and limited to making them passive.

\section{Method}

\section{Participants}

The data for the current study come from the Serbian Public Opinion Survey 2012 (SPOS). The SPOS is a post-election survey of public opinion conducted after the May 2012 parliamentary and presidential elections in Serbia. The study was designed to be a nationally representative, high-quality survey, focused on a broad set of attitudes, preferences, and opinions relevant to Serbian political life. It was based on a random sample with multiple stages of selection. The survey was conducted using the computer-assisted personal interviewing mode. Data collection began on December 21, 2012, and ran through to February 10, 2013. The sample included 1568 voting age Serbian citizens. There were slightly more females $(51.6 \%)$, than males $(48.4 \%)$ in the sample and the average age was $52(S D=$ 17.49). Approximately one-fourth of the sample (26.6\%) consists of respondents with elementary educational level; $56.5 \%$ of respondents finished secondary level of education, while $16.8 \%$ graduated at the faculty. Average monthly household income was in a range from 30000-39999 RSD. The statistical analyses presented below include a combined sampling and demographic weight, which means that the analysed sample is representative of the Serbian adult population in terms of age, gender, education, and urban-rural residence.

\section{Data and measures}

Authoritarianism. A short, six items scale, which is formulated on the basis of the well-known F scale (Adorno et al., 1950) and the RWA scale (Altemeyer, 1988) was used as a measure of authoritarianism. Similar scales were used and validated in previous studies (Pavlović, 2014; Todosijević, 2006). Each item was followed by a five-point Likert scale. Authoritarianism was operationalized as the first principal component (38\% of the total explained variance, $\alpha=.65$ ). All items have shown positive factor loadings on the first component (see Appendix A, Table A1). Higher scores imply higher authoritarianism.

Political knowledge. Four multiple-choice question knowledge test was used to measure the level of respondents' political knowledge. The respondents answered by choosing one of the four offered answers to the following questions (correct answers are provided in parentheses): (1) Who was the Finance Minister before the recent election? (Mirko Cvetković), (2) What was the unemployment rate in Serbia as of April 2012? (25.5\%), (3) Which party or coalition came in second in seats in the National Assembly? ("Izbor za bolji život" - Boris Tadić), and 
(4) Who is the current Secretary-General of the United Nations? (Ban Ki-moon). These four questions cover the area of politics often used in the operationalization and measurement of political knowledge - the knowledge of factual politics and the knowledge of foreign affairs (e.g., Delli Karpini \& Keeter, 1993, 1996).

Each respondent could provide a correct, incorrect or don't know the answer. The number of correct answers was treated as a measure of the level of political knowledge, with higher scores implying more political knowledge. As such, the incorrect and "don't know" answers were treated as a single response category ${ }^{2}$. In order not to make the main analysis misleading, besides analysing the relationship between authoritarianism and the level of political knowledge, we also analysed the differences in the authoritarianism level between the respondents who gave one of the three possible answers to each political knowledge question (correct/incorrect/don't know). Additionally, we analysed the differences in the level of authoritarianism between three political knowledge groups of respondents on political knowledge test in general - those who systematically gave all of the correct answers (the informed group), those who gave only wrong answers (the misinformed group) and those who gave a DK answer to all of the questions (the uninformed group). In that way, it was possible to analyse the difference in being misinformed and uninformed in regard to authoritarianism in more detail.

Interest in politics. General interest in politics is assessed by the following question: "How interested would you say you are in politics - are you very interested, quite interested, hardly interested, or not at all interested?". The respondents made their estimation on a four-point scale ( 1 = Very interested, 2 = Quite interested, 3 = Hardly interested, $4=$ Not at all interested $)$. The scale was recoded so that higher scores imply higher interest in politics.

Campaign following. Specific interest in an election campaign is measured by the following question: "Some people don't pay much attention to political campaigns. How closely did you follow the election campaign - not closely at all, not very closely, fairly closely, or very closely?". The respondents made their estimation on a four-point scale ( 1 = not closely at all, $2=$ not very closely, $3=$ fairly closely, $4=$ very closely) . This is treated as a measure of the specific, up-to-date interest in politics. This question, as well as the political knowledge questions and interest in politics, has been extensively tested cross-nationally, since they form a part of the Module 4 questionnaire of the Comparative Study of Electoral Systems project (CSES; www.cses.org), which was an integral part of the questionnaire used in our study.

\footnotetext{
2 Some methodological issues regarding the status of "Don't know" answers are heavily debated in the literature. Some argue that when DK answers are included and offered to the respondents (even encouraged by formal instructions etc.), the test scores reflect not just political knowledge but the personalityrelated propensity to guess as well (Mondak, 1999, 2001). This implies that DK and incorrect answers should not be treated as a single category (Mondak \& Anderson, 2004). However, these methodological issues are beyond the scope of this paper. In our survey, DK answers were neither offered nor encouraged, but were registered by interviewers when spontaneously given by the respondent.
} 
Socio-demographic variables. The set of control variables includes measures of education, age, and income. Age is measured in years since birth. Educational level is measured in 8 degrees, following the International Standard Classification of Education, provided by the UNESCO (UNESCO Institute for Statistics, 2012). Household income level is operationalized via an eleven-point income scale (from $1=0-9999$ RSD to $11=100000$ RSD and more).

\section{Results}

In determining the relationship between authoritarianism and cognitive political involvement we proceed as follows. We will first present the inter-correlations of all the variables in the study. Then we will focus on the correlation between authoritarianism and political knowledge, general and specific political interest, after controlling for age, education, and income. In this step of the analysis, we will additionally stress the differences between being misinformed (i.e., giving an incorrect answer) and uninformed (i.e., giving "don't know" answer) in relation to authoritarianism using ANOVA and post-hoc tests.

Correlation coefficients between variables included in the analysis are shown in Table 1. Concerning the relationship between authoritarianism and political variables, significant correlation coefficient has been registered only between authoritarianism and political knowledge. The relationship is negative - those higher on authoritarianism are less knowledgeable of politics and vice versa, as expected. To each of the political knowledge questions, those lower on authoritarianism gave more correct answers than those higher on authoritarianism. The association is weakest in the case of the unemployment question, and strongest for the UN Secretary General item.

The results also show that one's authoritarianism level is not systematically related to general and specific interest in politics. In other words, there is no difference in the levels of authoritarianism between those politically indifferent and those who are politically interested.

In accordance with the previous studies, the three socio-demographic variables proved to be significant correlates of authoritarianism and the cognitive political involvement variables. Older respondents $(r=.22, p<.01)$, the lower educated $(r=-.23, p<.01)$ and lower socio-economic strata $(r=-.12, p<.01)$ were more authoritarian than the younger, educated and wealthier participants. In a similar vein, general political interest is positively correlated with education $(r=.17, p<.01)$, age $(r=.13, p<.01)$ and income $(r=.10, p<.01)$. Older $(r=.17$, $p<.01)$, more educated $(r=.13, p<.01)$ and more well-off citizens $(r=.07, p<$ $.01)$ were more prone to campaign following as well. Finally, education $(r=.28$, $p<.01)$ and income $(r=.17, p<.01)$ were positively correlated with political knowledge. There is no significant correlation between age and the overall political knowledge score $(r=-.01, p=.76)$. However, some of the individual political 
information questions were significantly correlated with age. Older respondents were somewhat better in answering the question about the finance minister $(r=$ $.09, p<.01)$, but the younger were more correct about the unemployment rate $(r$ $=-.07, p<.01$ ). Hence, there may be a specific affinity between age and knowledge of political information in specific areas. For younger people information about unemployment might be more relevant, for instance.

Table 1

Summary of intercorrelations, means and standard deviations for the political variables included in the analysis

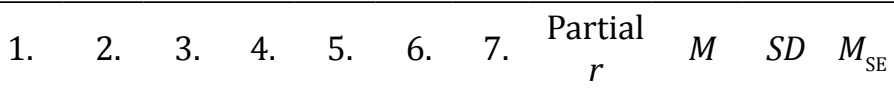

1. Authoritarianism

$-0.031 .020 .02$

2. Political knowledge score

$-.16^{* *}$

-.13** 1.781 .160 .03

3. Q. 1 (Finance Minister)

4. Q. 2 (Unemployment rate)

$-.09^{* *} .46^{* *} .11^{* *}$

$\begin{array}{llll}-.07 * & 0.17 & 0.38 & 0.01\end{array}$

5. Q. $3\left(2^{\text {nd }}\right.$ party in election)

$-.10^{* *} .66^{* *} .20^{* *} .12^{* *}$

$\begin{array}{llll}-.08 * & 0.58 & 0.49 & 0.01\end{array}$

6. Q. 4 (UN Secretary General)

$.13^{* *} .68^{* *} .25^{* *} .09^{* *} .27^{* *}$

$\begin{array}{llll}-.09 * * & 0.58 & 0.49 & 0.01\end{array}$

7. Interest in politics

8. Interest in election campaign

$$
\begin{array}{lllllll}
-.03 & .29^{* *} .21^{* *} .08^{* *} .20^{* *} .21^{* *} & -.03 & 2.15 & 0.88 & 0.02 \\
.01 & .30^{* *} .19^{* *} .08^{* *} .25^{* *} .20^{* *} .65^{* *} & -.01 & 2.21 & 0.83 & 0.02
\end{array}
$$

Note. Column Partial $r$ presents the correlation coefficients between authoritarianism and political variables, controlled for age, education, and income. ${ }^{* *} p<.01{ }^{*} p<.05$.

An important implication of these significant relationships between sociodemographic variables, authoritarianism, and political variables is that the influence of socio-demographic variables should be controlled for. Still, as shown in Table 1, controlling for the influence of the socio-demographic variables did not affect the previously observed relationships much. Correlation coefficients between authoritarianism and political knowledge remained significant and negative (although slightly lower in intensity). The correlation between authoritarianism and general and specific political interest remained non-significant.

Finally, we inspected the relationship between authoritarianism and political knowledge in more scrutiny and compared the level of authoritarianism between 
three political knowledge groups of respondents - those who were informed, misinformed and uninformed. On the first, $F(2,1456)=5.63, p<.01, \eta^{2}=.01$, second, $F(2,1456)=5.62, p<.01, \eta^{2}=.01$, third, $F(2,1456)=6.96, p<.01, \eta^{2}=.01$, and fourth knowledge question, $F(2,1456)=12.59, p<.01, \eta^{2}=.02$ the differences in authoritarianism between those who gave correct, incorrect and "don't know" answers are significant. As can be seen in Figure 1, those who gave the correct answer to each question are, on the average, the groups lowest in authoritarianism. Yet, the post-hoc tests revealed that the differences occurred mainly between those who gave correct answers on one side, and those who gave incorrect or don't know answers on the other (mean difference significant at .05 level in every case). In neither case, the mean differences between the misinformed and uninformed group proved to be significant.
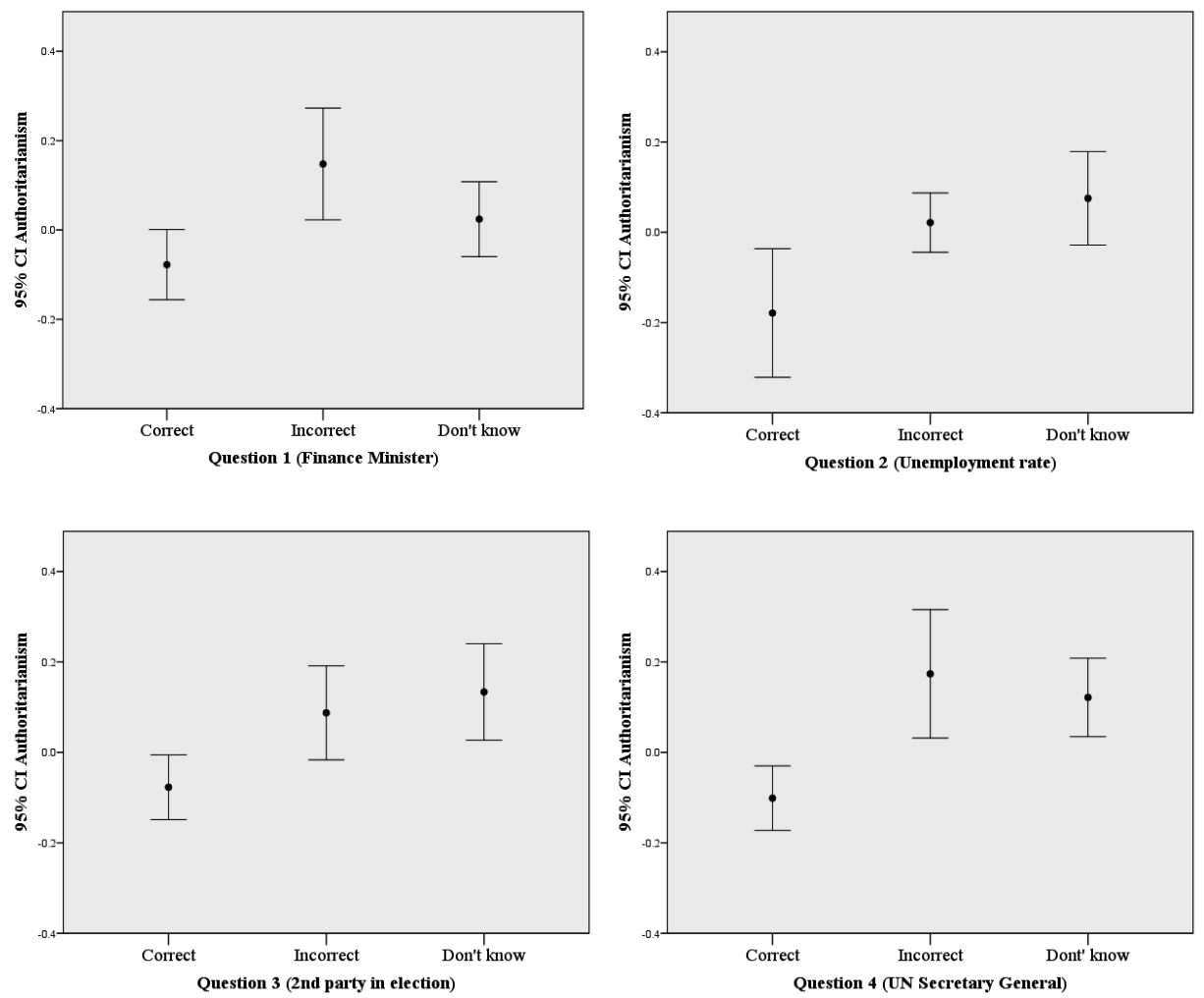

Figure 1. The average level of authoritarianism (with the 95\% CI) for the three political knowledge groups on four questions of the political knowledge test.

Similarly, the differences in authoritarianism between those who gave only correct (informed type), only incorrect (misinformed type) and only "don't know" (uninformed type) answers on each question were analysed as well (see Figure 
2). Although the number of respondents included in this analysis decrease dramatically ( 92 informed, 14 misinformed and 62 uninformed respondents in total), three groups of respondents still differ significantly in authoritarianism, $F(2,166)$ $=9.80, p<.01, \eta^{2}=.11$.

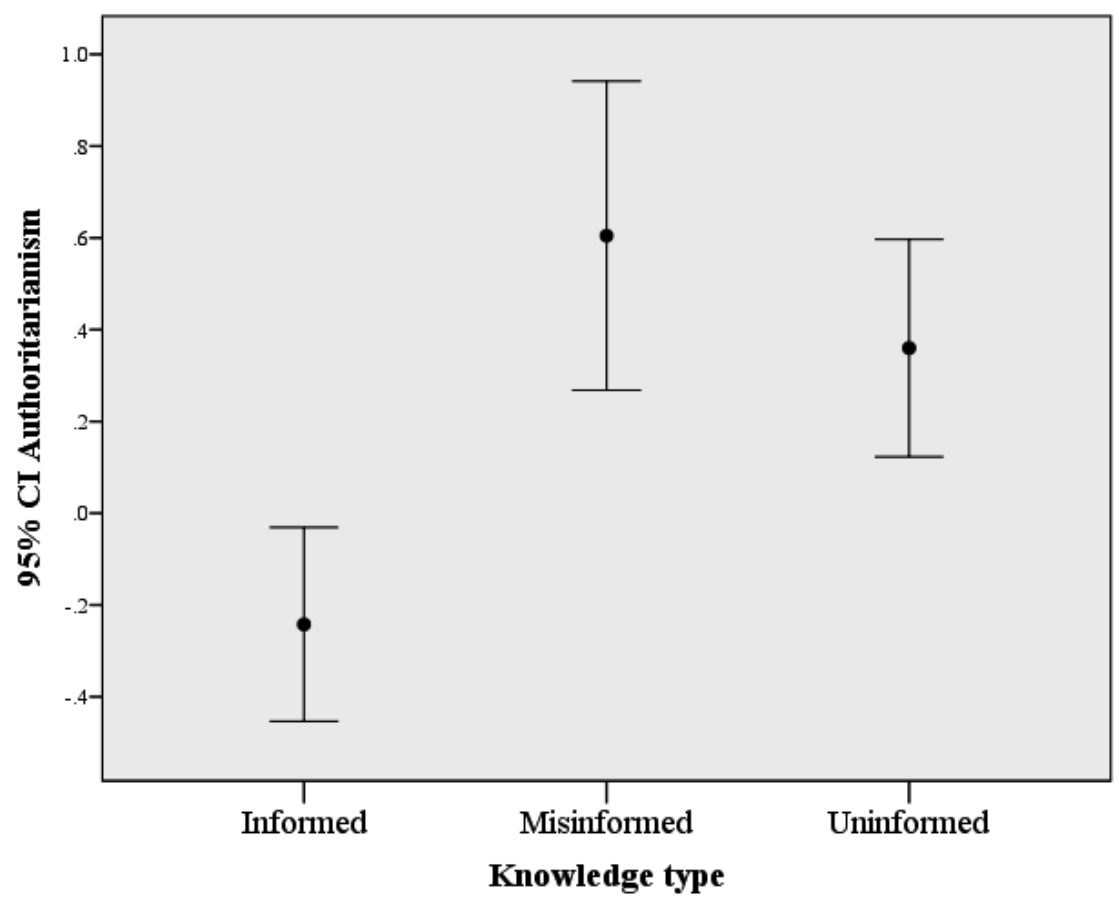

Figure 2. The average level of authoritarianism (with the 95\% confidence intervals) for the three political knowledge groups.

The informed group is, on the average, lowest on authoritarianism, while the misinformed group obtained the highest authoritarianism scores. However, the post-hoc tests revealed significant differences between the informed and misinformed respondents $(p<.05)$, as well as between the informed and uninformed ones $(p<.01)$. Still, the difference in authoritarianism between the two less politically sophisticated groups, the misinformed and uniformed, does not gain significance $(p=.69)$. In other words, the view that the higher authoritarian persons are more inclined to erroneously guess an answer than to simply say "don't know" is not supported by our data. 


\section{Discussion}

The results of this study have shown that persons who are higher on authoritarianism tend to be less politically knowledgeable. This is quite in line with the limited empirical evidence obtained on smaller, student samples and in different socio-cultural contexts (Peterson et al., 2002). Since the data for the present study were collected from the general public, i.e., respondents diverse in age, educational and income levels, and in a different political and cultural context, the link between authoritarianism and political knowledge seems robust, although of modest magnitude. It also proved that the link cannot be considered spurious, since it remained virtually unaffected after introducing the basic socio-economic controls.

Such findings support the theories that describe authoritarian individuals as tending towards political ignorance. Whether authoritarianism is associated with cognitive rigidity (Adorno et al., 1950), cognitive "shortcomings" (Altemeyer, 1996), identified as a part of a rigid construct system (Peterson et al., 2002) or a dogmatic world-view (Rokeach, 1960), it seems that the less accurate knowledge of politics accompanies higher authoritarianism. The question of the direction of influence, however, remains open. In the original conception, authoritarianism was treated as a personality trait, with deeply-seated, subconscious motivation, where avoidance of information inconsistent with adopted beliefs is psychologically adaptive.

Subsequent research found that authoritarianism indeed correlates with various relevant psychological variables - dogmatism (Rokeach, 1960), openness to experience (Peterson et al., 1997), the personal need for structure (Altemeyer, 1998) or the need for cognitive closure (Chirumbolo, 2001) (for a comprehensive overview, see Jost et al., 2003), all describing the tendencies of a person high on authoritarianism to seek certainty (i.e. avoid uncertainty), cling to familiar, arrive at premature conclusions and impose rigid categories and stereotypes. New pieces of information bring changes or call into question the established knowledge structures, which those seeking certainty urge to escape.

In a similar vein, lower knowledge on politics in general terms could be the result of a tendency of those higher on authoritarianism to neglect information critical to legitimate political authority (Adorno et al., 1950; Altemeyer, 1988; Cohrs \& Moschner, 2002). This interpretation would not apply to the present findings, though. The included measures of political knowledge are ideologically neutral, and therefore should not resonate especially with high authoritarianism. The idea that there may be some specific knowledge domains in which those higher on authoritarianism outperform those who are lower remains for the future research.

Contrary to the initial expectations, authoritarianism proved unrelated to the political interest variables. The included political interest variables represent an overall cognitive orientation towards the world of politics. Although originally described as a personality-related determinant of ideological preferences (Adorno 
et al., 1950), authoritarianism does not seem to have a prominent motivational potential in political terms. There are no differences in the authoritarianism level among those who are interested and those disinterested in politics in Serbia. This is different from Peterson et al. (2002), where in both of their student samples they found that authoritarianism "was significantly negatively related to personal interest in politics" (p. 104). As elaborated in the introductory part, the predictions about the relationships between authoritarianism and political interest were tentative. The bulk of theoretical arguments lead to an expectation of lower interest among highly authoritarian individuals. This, for instance, could be due to their lower openness to experience (e.g., McCrae, 1996). Yet, the expectation is not borne out. The hypothesis, proposed by Peterson et al. (2002), that it may be due to biased samples not containing the sufficient number of highly authoritarian individuals is not applicable here. The present sample was designed to be nationally representative of adult citizens of Serbia. Besides, interest and knowledge should be interrelated - a prominent interest should lead to greater knowledge and vice versa. Yet, authoritarianism is significantly related to political knowledge, but not to political interest. It could imply that the interested authoritarians gravitate towards the less informative sources of news and information.

Some alternative hypotheses will be offered here, one methodological and another contextual. The political interest variables, unlike the political information questions, are subjective, self-assessment variables. Hence, political interest answers might be subject to various influences, such as, for instance, social desirability. In particular, authoritarian individuals, being conventional, might feel more pressure to provide socially desirable answers (being interested in politics), and therefore directly affect the relationship examined here.

Another possibility is that expressions of political interest are affected by the political context. The survey was conducted some 6-7 months after the elections. In a study conducted some time before the 2012 elections in Serbia, it had been found that the supporters of the Serbian Progressive Party, the national conservative party that won the elections, were highest on authoritarianism (Kuzmanović, 2010). Hence, after the elections, the satisfaction with political life was probably higher among the more authoritarian individuals. At the time of the survey, those relatively lower on authoritarianism might have felt disappointed in the election outcome and the post-election developments, and therefore expressed lower political interest than otherwise. For instance, the previously ruling Democratic Party collapsed after the elections, and split into several fractions, thus providing a bleak political perspective for those who previously supported them.

The two factors are interrelated - the subjective character of the variable makes it more susceptible to the influence of the political context. We would suggest that these issues be addressed in future research since subjective political interest variables are often used in comparative research. This is somewhat different from the argument that in politically quiet times authoritarians are in their "normal", politically apathetic state and the feeling of threat would mobilize them 
(Doty, Peterson, \& Winter, 1991). The point advocated here is that certain sociopolitical conditions may have leveled up the expected relationship. Those low on authoritarianism may have expressed a lack of interest in politics, leveling off the differences in political interest in regard to authoritarianism.

\section{References}

Adorno, T. W., Frenkel-Brunswik, E., Levinson, D. J., \& Sanford, R. N. (1950). The authoritarian personality. New York: Harper.

Allport, G. (1954). The nature of prejudice. New York: Basic Books.

Altemeyer, R. A. (1981). Right-wing authoritarianism. Winnipeg, Manitoba: University of Manitoba Press.

Altemeyer, R. A. (1988). Enemies of freedom: Understanding right-wing authoritarianism. San Francisco: Jossey-Bass.

Altemeyer, R. A. (1996). The authoritarian spectre. Cambridge, MA: Harvard University Press.

Altemeyer, R. A. (2007). The Authoritarians. Retrieved from http://home. cc.umanitoba.ca/ altemey

Brown, R. (1965). Social psychology. New York: Free Press.

Chirumbolo, A. (2001). The relationship between need for cognitive closure and political orientation: The mediating role of authoritarianism. Personality and Individual Differences, 32, 603-610. doi:10.1016/S0191-8869(01)00062-9

Cohrs, C., \& Moschner, B. (2002). Antiwar knowledge and generalized political attitudes as determinants of attitude toward the Kosovo war. Peace and Conflict: Journal of Peace Psychology, 82, 139-155. doi: 10.1207/ S15327949PAC0802_03

Dalton, R. J. (1984). Cognitive mobilization and partisan dealignment in advanced industrial democracies. The Journal of Politics, 46, 264-284. doi: $10.2307 / 2130444$

Dalton, R. J. (2007). Partisan mobilization, cognitive mobilization and the changing American electorate. Electoral Studies, 26, 274-286. doi:10.1016/j.electstud.2006.04.009

Dalton, R. J., \& Wattenberg, M. P. (2000). Parties without partisans: Political change in advanced industrial democracies. Oxford: Oxford University Press.

Dekker, H. (1996). Democratic citizen competence - Political-psychological and political socialization research perspectives. In R. Farnen, F. Dekker, R. Meyenberg, \& D. German (Eds.), Democracy, socialization, and conflicting loyalties in East and West: Cross-national and comparative perspectives (pp. 386-404). London: Macmillan Press.

Delli Carpini, M., \& Keeter, S. (1991). Stability and change in the U.S. public's knowledge of politics. Public Opinion Quarterly, 55, 583-612. doi:10.1086/269283 
Delli Carpini, M., \& Keeter, S. (1993). Measuring political knowledge: Putting first things first. American Journal of Political Science, 37, 1179-1206. doi: $10.2307 / 2111549$

Delli Carpini, M., \& Keeter, S. (1996). What Americans know about politics and why it matters? New Haven: Yale University Press.

Doty, R. M., Peterson, B. E., \& Winter, D. G. (1991). Threat and authoritarianism in the United States, 1978-1987. Journal of Personality and Social Psychology, 61, 629-640. doi:10.1037/0022-3514.61.4.629

Doty, R. M., Winter, D., Peterson, B. E., \& Kemmelmeier, M. (1997). Authoritarianism and American students' attitudes about the Gulf War, 19901996. Personality and Social Psychology Bulletin, 23, 1133-1143. doi:10.1177/01461672972311002

Hinze, T., Doster, J., \& Joe, V. C. (1997). The relationship of conservatism and cognitive-complexity. Personality and Individual Differences, 222, 297-298.

Inglehart, R. (1979). Political action: The impact of values, cognitive level and social background. In S. Barns \& M. Kaase (Eds.), Political action: Mass participation in five western democracies (pp. 343-380). Beverly Hills: Sage.

Jost, J. T., \& Amodio, D. M. (2012). Political ideology as motivated social cognition: Behavioural and neuroscientific evidence. Motivation and Emotion, 36, 55-64. doi:10.1007/s11031-011-9260-7

Jost, J., Kruglanski, A., Glaser, J., \& Sulloway, F. (2003). Political conservatism as motivated social cognition. Psychological Bulletin, 129, 339-375. doi:10.1037/0033-2909.129.3.339

Klingemann, H. D. (1979). The background of ideological conceptualization. In S. Barns \& M. Kaase (Eds.), Political action: Mass participation in five western democracies (pp. 255-277). Beverly Hills: Sage.

Krampen, G. (2000). Transition of adolescent political action orientations to voting behaviour in early adulthood in view of a social-cognitive action theory model of personality. Political Psychology, 21, 277-293. doi:10.1111/0162895X.00188

Kuklinski, J., Quirk, P., Jerit, J., Schweider, D., \& Rich, R. (2000). Misinformation and the currency of democratic citizenship. Journal of Politics, 62, 790-816. doi:10.1111/0022-3816.00033

Kuzmanović, B. (2010). Autoritarnost - vapaj za jakim i pouzdanim vođama i disciplinom [Authorrtiarianism - A cry for strong and reliable leaders.]. In S. Mihailović (Ed.), Kako građani Srbije vide tranziciju [ How do citizens of Serbia see the transition] (pp. 87-104). Beograd: Friedrich Ebert Stiftung.

Lipset, S. (1959). Democracy and working-class authoritarianism. American Sociological Review, 24, 482-501.

McCrae, R. R. (1996). Social consequences of experiential openness. Psychological Bulletin, 1203, 323-337. 
McFarland, S. (2010). Authoritarianism, social dominance, and other roots of generalized prejudice. Political Psychology, 31, 453-477. doi: 10.1111/j.14679221.2010.00765.x

Meloen, J. D. (1993). The F scale as a predictor of fascism: An overview of 40 years of authoritarianism research. In W. F. Stone, G. Lederer, \& R. Christie (Eds.), Strength and weakness: The authoritarian personality today (pp. 47-69). New York: Springer-Verlag.

Meloen, J. (1996). Authoritarianism, democracy and education - A preliminary empirical 70-nation global indicators study. In R. Farnen, F. Dekker, R. Meyenberg, \& D. German (Eds.), Democracy, socialization, and conflicting loyalties in East and West: Cross-national and comparative perspectives (pp. 20-39). London: Macmillan Press.

Mondak, J. (1999). Reconsidering the measurement of political knowledge. Political Analysis, 8, 57-82. doi:10.1093/oxfordjournals.pan.a029805

Mondak, J. (2001). Developing valid knowledge scales. American Journal of Political Science, 45, 224-238.

Mondak, J., \& Anderson, M. R. (2004). The knowledge gap: A reexamination of gender-based differences in political knowledge. Journal of Politics, 66, 492-512. doi:10.1111/j.1468-2508.2004.00161.x

Pavlović, Z. (2012). Predictors and correlates of youth political knowledge in Serbia. Psihologija, 45, 433-449. doi:10.2298/PSI1204433P

Pavlović, Z. (2013a). Prediktori izborne apstinencije mladih u Srbiji [Predictors of youth electoral absenteeism in Serbia]. Primenjena psihologija, 6, 5-21.

Pavlović, Z. (2013b). Political culture vs. rational choice: Support for democracy in Serbia. In C. Florela Voinea, B. Todosijević, \& G. Boella (Eds.), Eastern European political cultures. Modeling studies (pp. 137-154). Bucuresti: Ars Docendi.

Pavlović, Z. (2014). Intrinsic or instrumental support for democracy in a postcommunist society. The case of Serbia. European Quarterly of Political Attitudes and Mentalities, 3, 31-42.

Pantić, D., \& Pavlović, Z. (2009). Political culture of voters in Serbia. Belgrade: Institute of Social Sciences.

Peterson, B. E., Doty, R. M., \& Winter, D. G. (1993). Authoritarianism and attitudes toward contemporary social issues. Personality and Social Psychology Bulletin, 19, 174-184. doi:10.1177/0146167293192006

Peterson, B. E., Smirles, K. A., \& Wentworth, P. A. (1997). Generativity and authoritarianism implications for personality, political involvement, and parenting. Journal of Personality and Social Psychology, 72, 1202-1216. doi:10.1037/0022-3514.72.5.1202

Peterson, B., Duncan, L., \& Pang, J. (2002). Authoritarianism and political impoverishment: Deficit in knowledge and civic disinterest. Political Psychology, 23, 37-112. doi:10.1111/0162-895X.00272 
Roets, A., \& Van Hiel, A. (2006). Need for closure relations with authoritarianism, conservative beliefs and racism: The impact of urgency and permanence tendencies. Psychologica Belgica, 463, 235-252. doi:10.5334/pb-46-3-235

Rokeach, M. (1960). The open and closed mind. New York: Basic Books.

Talhelm. T., Haidt, J., Oishi, S., Zhang, X., Miao, F., \& Chen, S. (2015). Liberals think more analytically more "WEIRD" than conservatives. Personality and Social Psychology Bulletin, 41, 250-267. doi:10.1177/0146167214563672

Tetlock, P. E. (1983). Cognitive style and political ideology. Journal of Personality and Social Psychology, 521, 118-128.

Todosijević, B. (2006). Politics in Serbia 1990-2002: A cleavage of world views. Psihologija, 39, 121-146.

Todosijević, B. (2013). Socijalni, psihološki i ideološki koreni nacionalističkih stavova u Srbiji. Psihologija, 46, 279-297. doi:10.2298/PSI130411005T

Todosijević, B., Pavlović, Z., \& Komar, O. (2015). Obrazovanje, ideologija i politika: Značaj razlika u nivou obrazovanja za političke podele u Srbiji i Crnoj Gori [Education, ideology, and politics: The importance of the differences in educational levels for the political cleavages in Serbian and Montenegro]. Srpska politička misao, Posebno izdanje, 125-152.

UNESCO Institute for Statistics (2012). International Standard Classification of Education ISCED 2011. Retrieved from http://www.uis.unesco.org/Education/Documents/isced-2011-en.pdf 
Zoran Pavlović

Odeljenje za

psihologiju, Filozofski fakultet, Univerzitet $u$ Beogradu, Srbija

\section{Bojan Todosijević}

\section{Centar za}

politikološka

istraživanja i javno

mnjenje, Institut

društvenih nauka, Beograd, Srbija

\section{AUTORITARNOST I POLITIČKA KOGNICIJA}

U radu se analizira veza između autoritarnosti i političke kognicije, operacionalizovane preko tri indikatora: politička informisanost, opšte interesovanje za politiku, i zainteresovanost za izbornu kampanju. Polazi se od hipoteze da su osobe sa višim stepenom autoritarnosti slabije politički informisane i manje zainteresovane za politiku, što proizilazi iz njhovog izrazitijeg otpora novim informacijama i menjanju usvojenih stavova. Ova hipoteza proizilazi iz klasičnog pisa autoritarne ličnosti, ali do sada nije adekvatno empirijski proverena. Podaci dolaze iz post-izbornog istraživanja javnog mnenja, sprovedenog nakon predsedničkih i parlamentarnih izbora 2012. godine. Anketirano je 1568 građana Srbije, odabranih metodom slučajnog izbora. Rezultati pokazuju da je autoritarnost u negativnoj korelaciji sa političkom informisanošću. S druge strane, opšta politička zainteresovanost i zainteresovanost za izbornu kampanju nisu u korelaciji sa nivoom autoritarnosti. Ove asocijacije su stabilne i nakon uvođenja statističke kontrole za osnovne socio-demografske variable. Dodatno poređenje pogrešno informisanih i neinformisanih grupa ispitnika (onih koji su dali pogrešne odgovore, i onih koji su odgovorili da ne znaju tačan odgovor) nije dalo podršku viđenju da su autoritarne osobe sklonije pogađanju odgovora nego tome da jednostavno odgovore da ne znaju. Analiza je zaključena tezom da je veza između autoritarnosti i političke informisanosti zasnovana na dubljim psihološkim procesima, dok je veza (odnosno nedostatak veze) sa interesovanjem za politiku više pod uticajem političkog konteksta.

Ključne reči: autoritarnost, politička informisanost, zainteresovanost za politiku, Srbija 


\section{Appendix A}

Table A

Authoritarianism Scale: Factor loadings on the first principal component

Loadings

The most important virtues a child has to learn are obedience and respect for authority.

Young people sometimes have rebellious thoughts, but as they grow up, they should condemn these and adapt.

Immoral conditions in our country are partly due to the fact that both teachers and parents forgot that physical punishment is still the best way of upbringing.

It would be better for everyone if the authorities censored the newspapers and films and other media so that rubbish be kept away from the youth.

Most of our social problems would be solved if we got rid of the immoral and pervert persons.

People can be divided into two groups: the strong and the weak.

Note. Extraction method - Principal Component Analysis; $38.18 \%$ of the explained variance. 